\title{
NUTRITIONAL COMPOSITION AND ACCEPTANCE OF CAKE ELABORATED WITH BEAUREGARD POTATO BIOFORTIFIED WITH CAROTENOIDS
}

\author{
COMPOSIÇÃO NUTRICIONAL E ACEITAÇÃO DE BOLO ELABORADO COM \\ BATATA BEAUREGARD BIOFORTIFICADA COM CAROTENOIDES
}

\author{
Juliany Sales RAMOS'; Maria do Carmo de Carvalho e MARTINS ${ }^{1}$; Alessandro de Lima ${ }^{1}$; \\ Fabricio Ibiapina TAPETY ${ }^{1}$; Camila Aparecida Pinheiro Landim ALMEIDA ${ }^{1}$ \\ 1. Centro Universitário UNINOVAFAPI, Mestrado Profissional em Saúde da família. Teresina, Piauí, Brasil. \\ julianysalesramos3@gmail.com; 2. Universidade Federal do Piaui. Departamento de Nutrição. Teresina, Piauí, Brasil.
}

\begin{abstract}
Beauregard biofortified sweet potato is a tuberous root with a high content of carotenoids whose consumption can bring beneficial effects on human health related to the biological actions of these substances. The objectives of this study were to evaluate the acceptance of cake made with sweet potato biofortified with carotenoids by school children enrolled in a school of the municipal education network of the city of Teresina PI. The sweet cake containing biofortified potato (Beauregard) (PC) was compared with standard sweet wheat flour (WC) cake formulation. The PC and WC products and the Beauregard potato were analyzed for centesimal composition (moisture, ashes, proteins, lipids and carbohydrates) and total carotenoid content. Acceptance of PC was assessed by means of an acceptance test with a hedonic scale of five points applied to 100 children from 08 to 10 years of age. The evaluation of the centesimal composition showed protein content corresponding to $2.1 \%$ in WC and $3.57 \%$ in PC, and of lipids of $5.16 \%$ in WC and $8.95 \%$ in PC. Regarding the moisture content, WC presented $32.5 \%$ and PC $38.44 \%$. The content of fixed minerals (ash) found in formulations was $1.9 \%$ and $1.26 \%$, respectively, in WC and PC. The carotenoid content ( $\mu \mathrm{g}$ of $\beta$ carotene. $\left.\mathrm{g}^{-1}\right)$ was significantly higher $(\mathrm{p}<0.05)$ in the biofortified potato $(3,200.01 \pm 0.02)$ and in the PC formulations $(3,666.17 \pm 2.55)$ and WC $(3,066.53 \pm 1.88)$ for common sweet potatoes $(2.200,23 \pm 1.63)$. In the five-point facial hedonistic acceptance test, the formulation containing biofortified potato (PC) obtained a significantly higher score $(\mathrm{p}<0.05)(4.24 \pm 0.93)$ when compared to the WC formulation $(3.75 \pm 1.19)$. The biofortified potato and the cake containing the biofortified potato presented some characteristics related to the centesimal composition similar to those found in WC and the content of carotenoids in PC larger than those of WC. Because sweet cake is a food product, generally well accepted by children and adults, PC's greater acceptance of WC suggests its promising potential for consumption by the population.
\end{abstract}

KEYWORDS: Beauregard potato. Infant nutrition. Carotenoids. Fortified foods.

\section{INTRODUCTION}

Vitamin A deficiency (DVA) is one of the major nutritional deficiency problems of public health impact, causing numerous diseases such as night blindness and xerophthalmia, as well as premature death in infants (RODRIGUEZAMAYA, 2008). Several studies have also shown that childhood diseases such as measles, diarrhea, respiratory tract infections and parasitic intestinal infections are strong indicators of hypovitaminosis A, especially in poorer regions (RODRIGUEZAMAYA, 2008).

The World Health Organization (OMS, 2009) estimates that at least one third of preschool children are affected by chronic vitamin A deficiency (with clinical symptoms) or marginal (subclinical) vitamin A deficiency. In Brazil, the prevalence of DVA is higher in the Northeast region and in areas with lower human development index (HDI), and is mainly due to the reduced consumption of food sources of vitamin A (SOUZA; VILAS BOAS, 2002).

Changes in infant feeding in recent years, evidenced by the high consumption of high-calorie and nutrient-poor foods may be directly related to the increased incidence of this deficiency. In this sense, the use of foods of high nutritional quality appears as a way to improve infant feeding, bringing benefits associated with health (COELHO, 2010).

Access to biofortified cultivars is an alternative to provide more nutritious food can help to meet the nutrient deficiency, and thus contribute to the reduction of the number of cases of hypovitaminosis in Brazil (STEVENS, WINTERNELSON, 2008). Food biofortification is an alternative strategy in the fight against hypovitaminosis $\mathrm{A}$ and aims to raise $\beta$-carotene 
levels in foods typically consumed by groups at risk of vitamin A deficiency (WELCH, 2013).

Beauregard sweet potato is an orangeintense tuber that has a high content of $\beta$-carotene, a precursor compound of vitamin A (SIMONNE et al., 1993; EMBRAPA, 2014). In the human body, beta-carotene obtained from food is transformed into vitamin $\mathrm{A}$, which is essential for the development of organs of vision, skin formation and body growth (MELO, SILVA, MOITA, 2010). In the food industry, carotenoids are used as natural food dyes to replace synthetic dyes, which have greater allergenic and carcinogenic potential. They also act as antioxidant compounds that combat free radicals (MATIOLI; RODRIGUEZ-AMAYA, 2003; MORAIS, 2006).

Due to its high content of $\beta$-carotene, the Beauregard potato can be used as a partial substitute for wheat flour in the manufacture of cakes, cookies and other products used in infant food (RODRIGUES-AMAYA et al., 2011). The use of biofortified foods in conventional products is a complex and challenging task, especially the acceptance of these foods in the school environment. Considering the importance of biofortified potatoes in food for the possible benefits associated with it, it is stressed the necessity of its conventional use and in the preparation of food products of great acceptance by the population. In this sense, two cake formulations were prepared and tested, being a standard formulation using wheat flour and another with biofortified potato, which were evaluated for carotenoid content and centesimal composition, as well as their acceptance by children of 08 to 10 years old. Therefore, the objectives of this study were to evaluate the acceptance of cake made with sweet potato biofortified with carotenoids by school children enrolled in a school of the municipal education network of the city of Teresina PI.

\section{MATERIAL AND METHODS}

\section{Obtaining biofortified potatoes}

Approximately $10 \mathrm{~kg}$ of biofortified sweet potatoes produced in the city of Teresina-PI in the year 2016 were obtained. The samples of Beauregard potatoes were selected according to their physical integrity and later transported in an isothermal container to the Food Analysis Laboratory of the Federal Institute of Piauí (IFPI) Campus Teresina South Zone, where they were sanitized for use in the preparation of formulations.

\section{Processing the wheat and biofortified potato sweet cake}

Two formulations were prepared, one of wheat cake (standard) and one of biofortified potato (Beauregard) (Table 1). For elaboration of the standard cake were added the planetary mixer the ingredients egg yolks, sugar and margarine, beating continuously. Then the milk, the wheat flour, the yeast and the egg whites were added, mixing well with the global beater. The dough was smeared with margarine and wheat flour and brought to the preheated medium oven for about 45 minutes.

In the preparation of the biofortified potato cake, sweet potatoes were cooked in waterimmersed shells at $100{ }^{\circ} \mathrm{C}$ for 20 minutes. Next, the peel was removed and the potatoes were passed, still hot, on the Phillips processor. Milk, egg yolks, sugar, yeast and egg whites were added later, mixing well with the spatula. The dough was deposited in a greased form with margarine and wheat flour and routed to the preheated medium oven for about 45 minutes at $180{ }^{\circ} \mathrm{C}$

Table 1. Formulation of the preparations analyzed.

\begin{tabular}{lll}
\hline Ingredients & $\begin{array}{l}\text { Wheat flour cake } \\
\text { (Standard Formulation) }\end{array}$ & $\begin{array}{l}\text { Potato Cake (Biofortified Potato } \\
\text { Formulation) }\end{array}$ \\
\hline Wheat flour & $480 \mathrm{~g}$ & - \\
Batata Beauregard & & $480 \mathrm{~g}$ \\
Sugar & - & $360 \mathrm{~g}$ \\
Eggs & $360 \mathrm{~g}$ & $200 \mathrm{~g}$ \\
Butter & $200 \mathrm{~g}$ & $(4 \mathrm{units})$ \\
Milk & $(4 \mathrm{units})$ & $250 \mathrm{~g}$ \\
Yeast & $250 \mathrm{~g}$ & $240 \mathrm{~mL}$ \\
\hline Caption: Formulation A: Wheat cake; Formulation B: Biofortified Potato Cake; Wheat cake: 12 servings; Potato cake: 10 servings
\end{tabular}




\section{Determination of the centesimal composition}

The centesimal analysis was carried out at the Nucleus of Studies, Research and Food Processing (NUEPPA), being the determinations carried out in triplicate of common sweet potato and Beauregard potato, and in the standard and Beauregard potato based formulations.

The analyzes were performed as described below: Moisture: According to the Association of Official Agricultural Chemists Official (AOAC, 2011), which consists of drying at $105{ }^{\circ} \mathrm{C}$ until constant weight; Ash: in muffle at $550^{\circ} \mathrm{C}$, according to AOAC methodology (2011); Proteins: through the evaluation of the total nitrogen of the sample by the Kjeldahl method, determined at semimicro level (AOAC, 2011). The nitrogen conversion factor for protein of 6.25; Lipids: the samples were evaluated in a soxhlet extractor, using petroleum ether as solvent (AOAC, 2011). Carbohydrates: by theoretical calculation (by difference) in the results of the samples, according to the formula: $\%$ Carbohydrates $=100-(\%$ moisture $+\%$ protein $+\%$ lipids $+\%$ ash); The total calories (kcal) were calculated in relation to $100 \mathrm{~g}$ of the sample, using the following values for lipids $(8.37 \mathrm{kcal} / \mathrm{g})$, protein (3.87 kcal/g) and carbohydrates (4.11 kcal/g) (MERRILL, WATT, 1973).

\section{Total carotenoid}

The determination of the carotenoid content was performed according to the method described by Rodrigues Amaya (2012). The reading was carried out in a spectrophotometer at $450 \mathrm{~nm}(\lambda \max$ $\beta$-carotene), using petroleum ether as white. The results were expressed as $\mu \mathrm{g} \mu$-carotene. $\mathrm{g}^{-1}$ sample.

\section{Acceptance of the product}

In order to allow the evaluation of the acceptance of the elaborated products, 100 testers of both sexes between the ages of eight and ten years were recruited, to whom a hedonic facial scale was applied. For the acceptance test, the two formulations were arranged in trays with codes of three digits randomized and different for each taster, being evaluated the global acceptance by applying a facial hedonic scale of 5 points ranging from 01 (Hate it) to 05 (Love it) DUTCOSKY facial, 2011. During the acceptance test, mineral water was made available to the tasters to minimize the residual effect between one sample and another.

In order to calculate the acceptability index, the acceptance test cards were collected and the sum of responses given were considered with the "faces": I liked (4) and I loved (5), the frequency was expressed in percentage terms.
Those responsible for the children received information about the objectives of the study, and clarification on the potential benefits and risks associated with the study. The children received information about their participation. To confirm participation in the study, the participants parents signed a Free and Informed Consent Term (TCLE).

\section{Statistical analysis of data}

The ASSISTAT statistical program, version 7.7 beta, was used to analyze the results. The comparison between the means of acceptance and carotenoid content was performed using the Student $t$ test. The level of significance was set at $p<0.05$.

\section{RESULTS AND DISCUSSION}

\section{Analysis of the centesimal composition and carotenoid content}

The results of the centesimal composition of the in natura version for sweet potato and biofortified potato, as well as of the standard food formulations and using Beauregard potato are presented in Table 2. Sweet potatoes (SP) have a high moisture content (69.54\%), corroborating the Brazilian Food Composition Table (TACO, as it per acronyms in portuguese), which indicates a $69.5 \%$ moisture content for raw sweet potato (Ipomoea batatas Lam.) (NEPA, 2011). The biofortified potato, however, had a lower percentage of moisture (25.28\%). According to Fellows (2006) and Cecchi (2007), the moisture content varies according to the food, its determination being of great importance to define the stability, quality and composition of the food, which may affect the storage, packaging and processing of the food.

The biofortified potato presented a high carbohydrate content $(73.42 \%)$ when compared to the common sweet potato (49.65\%), being such values higher than those found by Hacineaza et al. (2010) in cultivars of orange pulp and yellow pulp, whose values were $7.6 \%$ and $8.7 \%$, respectively.

The differences found in the chemical characterization of common and biofortified sweet potatoes in natura can be explained by their dependence on variety, soil type, fertilization, cultivation time and harvesting time (Carvalho et al, 1982). The results found for lipids and carbohydrates of biofortified sweet potato, demonstrate that it is better to be consumed than the common sweet potato, since it has a higher content of lipids and can be denominated as food of low glycemic index Fontes et al (2012). 
Table 2. Centesimal composition and carotenoid content of sweet potato, beauregard potato, wheat flour cake and Beauregard potato cake.

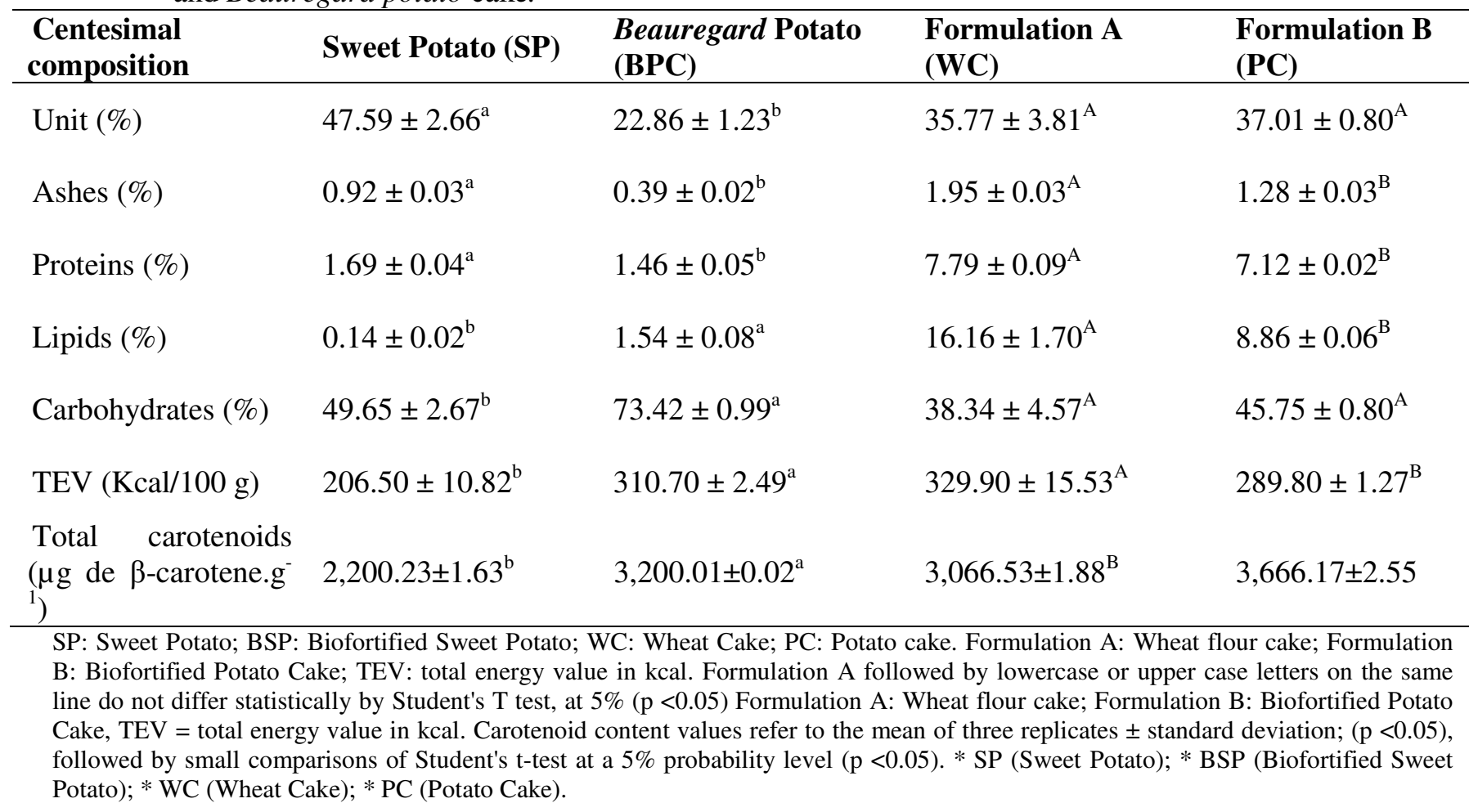

The production of unconventional farinaceous from roots that have high percentages of carbohydrate, such as the Beauregard potato, can make a source of income accessible to the population. According to Fasolin et al (2007), in many regions where wheat derivatives are not sufficient to meet the needs of the population, the inclusion of differentiated flours to food is a valid option. However, consumers should be offered a product of good nutritional and sensory quality. The biofortified potato in addition to being rich in carotenoids its cost is very similar to that of the common sweet potato and lower in relation to the cost of the wheat flour, it can still be an alternative to the diet of celiacs being able to have the wheat flour totally replaced by the pulp or biofortified potato flour in many recipes.

In relation to the protein content, it was possible to verify that the biofortified potato had a higher percentage $(1.46 \%)$ when compared to the common sweet potato (1.69\%). The two formulations $\mathrm{WC}$ and PC presented higher protein values (7.79 and $7.12 \%$, respectively) than those described in potatoes. This difference is possibly related to the presence of other foods used as ingredients (eggs, whole milk) and which are considered to be good protein sources.

In addition, a high content of carbohydrates and proteins in tubers such as sweet potatoes was also highlighted in a study by Dincer et al (2011), which analyzed three cultivars of sweet potatoes (Ipomoea batatas (L.) Lam) and observed values between 63.9 and $64.9 \%$ of carbohydrates and 4.3 to $5.1 \%$ of proteins.

The potato cake presented higher moisture contents $(37.01 \%)$ when compared to the wheat flour cake $(35.53 \%)$, which corroborates the moisture content found in the Brazilian food composition table (TACO, 2011) for cake made with aipim root $(34.1 \%)$. This increase in moisture content occurs due to the presence of water in the potato, which is larger than in the farinaceous ones like wheat, making the $\mathrm{BB}$ cake more moist. According to the physico-chemical composition presented by the flour, it occurs at this stage the formation of a colloidal system, which involves lipids, sugars, minerals and proteins, among others (GUTKOSKI; NETO, 2002).

As regards fixed minerals (ashes), lower levels were found in the biofortified potato $(0.39 \%)$ when compared to sweet potatoes $(0.92 \%)$. Both results were lower than those found by Mei et al. (2010), which verified in 10 sweet potato cultivars values between 1.6-3.0\% of ash; and by Dincer et al (2011) in three cultivars of sweet potato (Ipomoea batatas (L.) Lam), which presented values between 2.1-2.5\%.

The present study revealed a higher lipid content in biofortified sweet potato $(1.54 \%)$ when compared to common potato $(0.14 \%)$, presenting a 
significant difference. Noleto et al. (2015). In fact, other studies evaluating common sweet potato showed lipid levels below $1 \%$. In this sense, Mei et al. (2010) verified in 10 common sweet potato cultivars, ranging from 0.2 to $0.6 \%$ in lipid quantification. On the other hand, in biofortified sweet potato starch, Nascimento (2013) found a lipid content of $0.6 \%$.

The increase in lipid concentration in biofortified sweet potatoes is attributed to the enrichment with liposoluble substances, such as carotenoids, which are also extracted during the analysis.

Due to this, the formulation that presented $8.95 \%$ of biofortified potato had higher values when compared to the standard formulation $(5.17 \%)$. The total energetic value of biofortified sweet potato (306.13) was higher than common sweet potato (118.73) and BT (287.81) and BB (285.91) similar data were found in the amaranth cake that presented the $(50 \%)$. The lipid content is higher than the lipid content of the amaranth (8\%) (CAPRILES et al, 2006), with $50 \%$ being polyunsaturated, $25 \%$ monounsaturated and $25 \%$ saturated.

Regarding the lipid content of the formulations, the one with potato $(8.86 \%)$ had higher values when compared to the standard formulation (16.16\%). The total energy value of biofortified sweet potato $(289.80 \%)$ was superior to common sweet potato $310.70 \%)$ and WC (206.50\%) and PC (310.70).

The content of carotenoids present in the Beauregard potato was 3,200.01 $\mu \mathrm{g}$ of $\beta$-carotene.g${ }^{1}$ sample was higher than in common sweet potato $\left(2,200.23 \pm 1.63 \mu \mathrm{g} \beta\right.$-carotene. $\left.\mathrm{g}^{-1}\right)$ and lower than those described by Nascimento et al (2013) in sweet potato starch in which the content was $180 \mu \mathrm{g} \cdot \mathrm{g}^{-1}$ of the sample, and Rodrigues-Amaya et al (2011) found $130 \mu \mathrm{g} . \mathrm{g}^{-1}$ of biofortified fresh root. The content was higher in the PC formulation $(3,666.17$ $\pm 2.55 \mu \mathrm{g} \beta$-carotene. $\left.\mathrm{g}^{-1}\right)$ when compared to WC $\left(3,066.53 \pm 1.88 \mu \mathrm{g} \beta\right.$-carotene. $\left.\mathrm{g}^{-1}\right)$. The higher content in WC compared to those found in common sweet potatoes are possibly related to the addition of animal foods rich in carotenoids such as milk and eggs

Table 3. Notes of the averages of the acceptance test using face scale.

\section{Formulation A(Mean \pm SD $)$}

\section{Formulation B(Mean \pm SD)}

\begin{tabular}{lll}
\hline Means & $3.75 \pm 1.19^{*}$ & $4.24 \pm 0.93^{*}$ \\
\hline IC 95\% & $3.51-3.99$ & $4.06-4.43$
\end{tabular}

\footnotetext{
* Indicates a statistically significant difference between the means by means of the unpaired Student $\mathrm{t}$ test, considering $\mathrm{p}<0.05$. Values expressed as mean \pm standard deviation $(\mathrm{SD}), \mathrm{n}=100$; 95\% CI - 95\% confidence interval; Legend: formulation $\mathrm{A}$ - wheat cake; Formulation B - potato cake.
} 
Regarding the acceptance index, it is verified in Figure 1 that the formulation of the biofortified potato cake obtained greater acceptance when compared to the standard cake using wheat flour, were considered accepted $(>70 \%)$ as shown in figure 1, highlighting It was found that obtaining notes on the face scale mostly at values of 4 and 5 (65\% wheat cake, $86 \%$ potato cake). According to Souza (2007) a food with more than $70 \%$ of approval indicates good acceptance. In this study, the formulation of cake with biofortified potato with carotenoids presented good acceptance in the group of children, but can be consumed by adults.

However, some limitations were found such as the commercialization of beuregad potatoes and the analysis of fiber content in potatoes. However, biofortified potato cake presented high nutritional value when compared to wheat flour cake, it can still be used in the celiac diet because wheat flour has been totally replaced by biofortified potato pulp that has high carotenoid content and low cost, since the kilo of biofortified potatoes is much cheaper than one kilo of wheat flour.

\section{Acceptability}

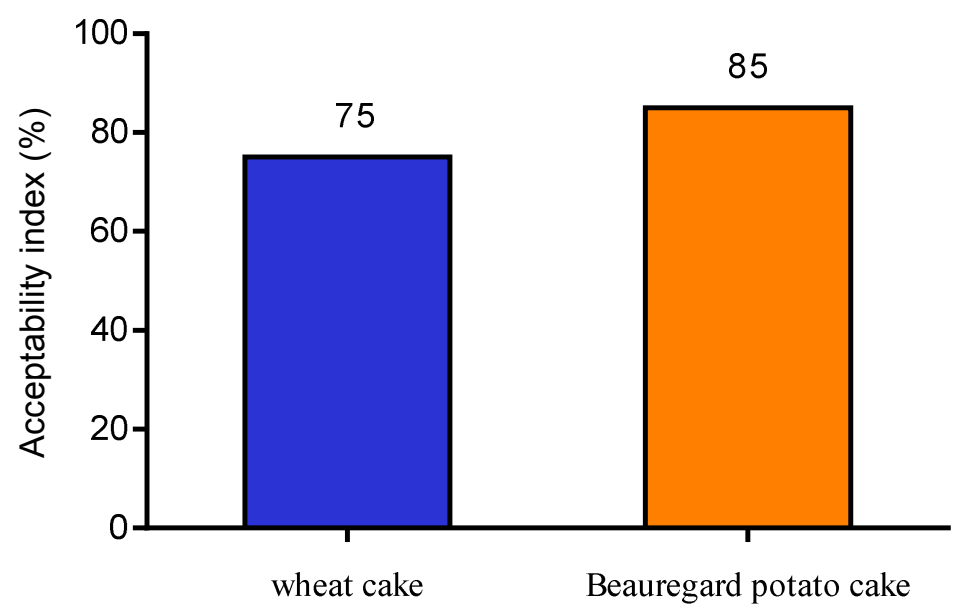

Figure 1. Acceptance rate of Beauregard potato and wheat cake formulations..

\section{CONCLUSION}

The carotenoid content and the acceptance of the biofortified potato cake were higher when compared to the standard cake made with wheat flour, although the total energy value was similar.
Because sweet cake is a food product, generally well accepted by children and adults, the greater acceptance of biofortified potato cake suggests its promising potential for consumption by children and also by adults.

RESUMO: A batata-doce Beauregard biofortificada é uma raiz tuberosa com alto teor de carotenoides, cujo consumo pode trazer efeitos benéficos na saúde humana relacionados com as ações biológicas dessas substâncias. Os objetivos deste estudo foram avaliar a aceitação de bolo elaborado com batata doce biofortificada com carotenoides por crianças em idade escolar matriculados em uma escola da rede municipal de ensino da cidade de Teresina PI. O bolo doce contendo batata biofortificada (Beauregard) (BB) foi comparado com formulação padrão de bolo doce de farinha de trigo (BT). Os produtos BB e BT e a batata Beauregard foram analisados quanto à composição centesimal (umidade, cinzas, proteínas, lipídeos e carboidratos) e conteúdo de carotenóides totais. A aceitação do BB foi avaliada por meio de teste de aceitação com escala hedônica facial de cinco pontos aplicado em 100 crianças de 08 a 10 anos de idade. A avaliação da composição centesimal mostrou conteúdo protéico correspondendo 2,1\% no BT e 3,57\% no BB, e de lipídios de $5,16 \%$ no BT e $8,95 \%$ no BB. Em relação ao teor de umidade, o BT apresentou 32,5\% e BB 38,44\%. O teor de minerais fixos (cinzas) encontrado nas formulações foi de 1,9\% e 1,26\%, respectivamente, no BT e BB. $\mathrm{O}$ conteúdo de carotenoides ( $\mu \mathrm{g}$ de $\beta$-caroteno. $\mathrm{g}^{-1}$ ) foi significativamente maior $(\mathrm{p}<0,05)$ na batata biofortificada $(3.200,01 \pm 0,02)$ e nas formulações BB $(3.666,17 \pm 2,55)$ e BT $(3.066,53 \pm 1,88)$ em relação à 
batata doce comum $(2.200,00 \pm 1,63)$. No teste de aceitação escala hedonica facial de cinco pontos a formulação contendo batata biofortificada (BB) obteve nota significativamente maior $(p<0,05)(4,24 \pm 0,93)$ quando comparada com a formulação BT $(3,75 \pm 1,19)$. A batata biofortificada e o bolo contendo a batata biofortificada apresentaram algumas características relacionadas à composição centesimal semelhantes àquelas encontradas no BT e conteúdo de carotenoides no BB maiores que os do BT. Por ser o bolo doce um produto alimentício, de modo geral, bem aceito por crianças e adultos, a maior aceitação do BB em relação ao BT sugere seu potencial promissor para consumo pela população.

PALAVRAS-CHAVE: Batata Beauregard. Nutrição da criança. Carotenoides. Alimentos fortificados.

\section{REFERENCES}

AOAC. Official Methods of Analysis of AOAC International. 14th ed. Arlington; 2011.

BLOEM, M. W.; PEE, S.; DANTON-HILL, I. D. New issues in developing effective approaches for the prevention and control of vitamin A deficiency. Food Nutriton Bulletin, v. 19, p. 37-48, 1998.

CECCHI H. M. Fundamentos teóricos e Práticos em Análise de Alimentos. $2^{\circ}$ ed. Editora Unicamp, São Paulo, 2007.

COELHO, R. G. Interações Nutricionais - parte 2: ao nível pós-absortivo. Rev Metab Nutr. v.2, n.4, p. 179-82, 1995

DINCER, M. et al. Efeitos do cozimento e ferver sobre as propriedades nutricionais e antioxidantes da batata doce [ Ipomoea batatas]. Cultivares Plant Foods for Human Nutrition, v.66, pp. 341-347, 2011.

DUTCOSKY, S. D. Análise sensorial de alimentos. Curitiba: Champagnat, 2011.

EMBRAPA, 2014. Pesquisadora do Maracanã melhora produtividade de batata-doce biofortificada [noticia na Internet]. Available from: http://portal.ifma.edu.br/2014/03/26/pesquisadora-do-maracana-criatecnica-para-aumentar-produtividade-de-batata-doce-biofortificada/

FAILLA, M. L.; CHITCHUMROONCHOKCHAI, C. In vitro models as tools for screening the relative bioavailabilities of provitamin A carotenoids in foods. Washington, DC: HarvestPlus, 2005.

FASOLIN, L. H.; et al. Biscoitos produzidos com farinha de banana: avaliações química, física e sensorial. Revista Ciência e Tecnologia de Alimentos. v. 27, n. 3, 524-529, 2007.

FELLOWS P. J. Tecnologia do Processamento de Alimentos: Princípios e prática. Tradução: Florencia Cladera Oliveira et al - $2^{\circ}$ edição - Porto Alegre: Artmed, 2006.

FERREIRA, V. A.; MAGALHAES, R. Nutrição e promoção da saúde: perspectivas atuais. Cadernos de Saúde Pública, Rio de Janeiro, v. 23, n. 7, p. 1674-1681, July 2007.

HACINEAZA E.; et al. Comparative study on the B-carotene content and its retention in yellow and orange fleshed Sweet Potato flours. Association for Strengthening Agricultural Research in Eastern and Central Africa, 2010.

K'OSSAMBO, L. M.; et al. Influence of age, farming site, and boiling on pro-vitamin A content in sweet potato (Ipomoea batatas (L.) Lam.) storage roots. Journal of Food Composition and Analysis, v. 11, p.305321, 1998. 
MATIOLI, G; RODRIGUEZ-AMAYA, D. B. Microencapsulação do licopeno com ciclodextrinas. Ciência Tecnologias e Alimentos, Campinas, v. 23, supl. p. 102-105, 2003.

MEI, T.H.; MU, J.J.; Composition and physicochemical properties of dietary fiber extracted from residues of 10 varieties of sweet potato by a sieving method. Journal of Agricultural and Food Chemistry, v. 58 , pp. 7305-7310, 2010.

MELO, W. F.; SILVA, J. B. C.; MOITA, A. W. Avaliação da produtividade de clones de batata-doce ricos em provitamina A junto a agricultores familiares. 2010. Horticultura Brasileira 28: S2302-S2306.

MERRILL, A.L.; WATT, B.K. Energy value of foods: basis and derivation. Agriculture Handbook No. 74, 1973.

MORAIS, N. R. L., et al . Prospecção fitoquímica e avaliação do potencial antioxidante de Cnidoscolus phyllacanthus (müll. Arg.) Pax \& k.hoffm. Oriundo de apodi - RN. Revista brasileira de plantas medicinais, Botucatu, v. 18, n. 1, p. 180-185, 2016.

NASCIMENTO, K. O., et al. Caracterização química e informação nutricional de fécula de batata-doce (Ipomoea batatas L.) orgânica e biofortificada. Revista Verde de Agroecologia e Desenvolvimento Sustentável, v. 8, n. 1, p. 132-138, 2013.

NEPA. Tabela brasileira de composição de alimentos (TACO). Universidade Estadual de Campinas (UNICAMP). 4. ed. Campinas, 2011. 161 p.

NETO, J. J. L.; et al. Impact of bioaccessibility and bioavailability of phenolic compounds in biological systems upon the antioxidant activity of the ethanolic extract of Triplaris gardneriana seeds. Biomedicine and Pharmacotherapy, v.88, n.1, p.999-1007, 2017.

RODRIGUEZ-AMAYA, D. B., et al. Updated Brazilian database on food carotenoids: Factors affecting carotenoid composition. Journal of Food Composition and Analysis, v. 21, n. 6, p. 445-463, 2008.

SIMONNE, A. H.; KAYS, S. J.; KOEHLER, P. E. Assessment of betacarotene content in sweetpotato breeding lines in relation to dietary requirements. Journal of Food Comp Anal, v. 6, p. 336-345, 1993.

SOUSA, M.F; HAMANN, E. M. Programa Saúde da Família no Brasil: uma agenda incompleta?. Ciênc. saúde coletiva, Rio de Janeiro, v. 14, supl. 1, p. 1325-1335, Oct. 2009.

STEVENS, R.; WINTER-NELSON, A. Consumer acceptance of provitamin A - biofortified maize in Maputo, Mozambique. Food Policy, v. 33, n. 4, p. 341-351, 2008.

TEIXEIRA, E.; MEINERT, E.; BARBETTA, P. A. Análise sensorial dos alimentos. Florianópolis, SC: UFSC, 1987 